DOI: https://doi.org/10.31933/dijms.v2i4

Received: 30 January 2021, Revised: 7 March 2021, Publish: 15 April 2021

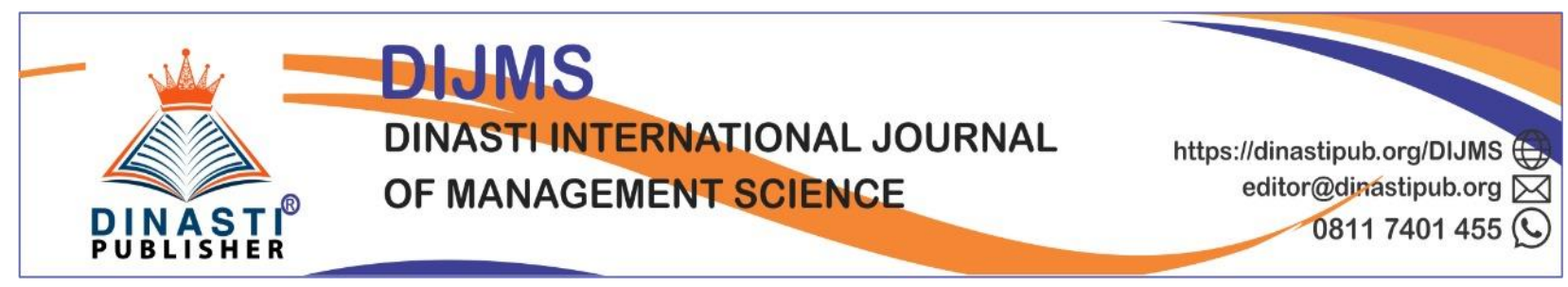

\title{
FACTORS AFFECTING CONSUMER BEHAVIOR IN BUYING DECISION OF SUZUKI ERTIGA CAR IN CILEGON CITY, BANTEN
}

\author{
Yuwan Ditra Krahara ${ }^{1}$, Alugoro Mulyowahyudi ${ }^{2}$ \\ 1) Universitas Mercu Buana, Jakarta, Indonesia, yuwanditra820@gmail.com \\ 2) Universitas Mercu Buana, Jakarta, Indonesia, alugoro_m@yahoo.com
}

Corresponding Author: First Author ${ }^{1}$

\begin{abstract}
This study aims to analyze the factors that influence consumer behavior in the decision to purchase a Suzuki Ertiga car in Cilegon City Banten. The population in this study were customers in the city of Cilegon who bought a Suzuki Ertiga with 200 participants. Methods of data analysis using the Structural Equation Model-Partial Least Squares (SEMPLS). The software that is used to process and analyze data obtained from this study is the Smart PLS version 3.3.2. The results of the study found that Product Quality, brand awareness and promotion had a positive and significant effect on purchasing decisions.
\end{abstract}

Keyword: Product Quality, Brand Awareness, Promotion, Purchase Decision

\section{INTRODUCTION}

The automotive industry in Indonesia is currently on the rise and in a very fast development, with various automotive industries launching their newest products. This has resulted in increasingly competitive automotive industry in Indonesia. Vehicle manufacturers try to innovate but still try to meet consumer demand. (Wangean \& Mandey, 2014) Type of vehicle "MPV" (Multi Purpose Vehicle) This type of car is in great demand by consumers because it has good comfort and safety, brand competition for each vehicle product is getting tougher, along with the number of dealers who offer various products. . vehicles, designs, and types, so that consumers can search for products and brands. (Wibisono, 2017). Currently it is still the most popular in the Indonesian market, the price is quite affordable and can accommodate a large number of passengers and is one of the reasons why most Indonesians choose to buy this type of car. (Carmudi, 2020). still managed by Japanese manufacturers until now, 12 Japanese four-wheeled vehicle brands indicate entering the domestic market (Otoflik, 2020).

The Toyota Avanza, which reached 114,520 units in 2017, fell by 7,0431 units in 2018 and then increased by 86,384 units in 2019 , outperforming its competitors who only sold 
11,351 units in 2017, but Suzuki Ertiga sales in the last three years were less. apart from the Toyota Avanza and Mitsubishi Expander. This phenomenon is different from the success of Suzuki Ertiga as one of the brands that received the Best Low MPV and Car Of The Year awards. (Suzuki.co.id, 2019). The researcher conducted a survey with 20 participants and found that Product Quality, Promotion and Brand Awareness as the three highest variables of the other variables constituted the highest number of respondents in the pre-survey, so the researcher would use these three variables as independent variables. Meanwhile, information obtained from written questions that can influence purchasing decisions is the dependent variable in the study.

Product quality has a positive and important effect on purchasing decisions. Product quality shows that the higher the quality of the product being offered, the higher the desire of consumers to decide to buy the product. (Amron, 2018) Meanwhile, according to preliminary research. It detects that product quality has a significant negative impact on purchasing decisions. (Tawas \& Pandensolang, 2015). Brand awareness has a positive and significant effect on purchasing decisions, so brand awareness is important for producers because consumers will tend to buy products that they know or remember. The higher the level of brand awareness, it means that the brand is growing in the mind or minds of consumers compared to other brands. (Subagja et al., 2019). However, this is not the case when his research says brand awareness has no significant impact on purchasing decisions. (Mustari et al., 2016). The promotion variable then has a significant positive effect on purchasing decisions. In a promotion, the marketing communication process occurs in the form of transfer of information that influences or persuades buyers or attracts customers and ultimately makes purchase decisions. (Rahman \& Sitio, 2020). However, this promotion does not have a significant impact on purchasing decisions. (Fong et al., 2015).

\section{LITERATURE REVIEW}

Consumer behavior as influence and cognition, behavior and dynamics of environmental interactions where humans make changes in their lives. (Peter \& Olson, 1987). Consumer behavior is the behavior displayed by consumers when looking for, buying, using, evaluating, and spending products and services that they hope will meet their needs (Schiffman \& Kanuk, 2008). Consumer behavior states that the limits of consumer behavior are actions that are directly related to the

acquisition, consumption and consumption of products and services, including the decisionmaking process that precedes and follows. (Peter \& Olson, 1987). It is the study of the processes that individuals or organizations and consumers use to find, select, use and dispose of products, services, experiences to meet their needs and their impact on consumers and society. (Mayil et al., 2016). The transformation of the marketing concept from just a sales concept to a consumer-focused marketing has resulted in buyer behavior becoming an independent discipline. (Jayaraj, 2017).

Purchasing decision is an integration process that is used to combine information to evaluate two or more alternative behaviors and choose one. (Amron, 2018). A set of factors that influence consumer purchasing decisions regardless of the situation and level of decision making, including external, internal, and marketing factors. (Salem, 2018). decisions are an important part of consumer behavior. It should be noted that purchasing decisions are not 
completed with the purchase of goods or services, but also post-purchase activities consist of consumer behavior (Khuong \& Duyen, 2016). a decision is an option that consists of two or more alternative options. Alternative options must be available to a person when making decisions. (Schiffman \& Kanuk, 2008).

Product Quality If a product meets customer expectations, the customer will be satisfied and consider the product acceptable or even of good quality. If expectations are not met, the customer will evaluate a low quality product. (Sheroog Alhedhaif et al., 2016). The definition of product quality varies between the perspectives considered (Garvin 1983). Many researchers determine product quality from a user's perspective in terms of the customer's overall assessment of a product. (Xu et al., 2017). Product quality is a very important thing that every company must face if it wants the products to be able to compete in the market and meet the expectations of every consumer. (Broto \& Wenas, 2016). Product quality is the ability of a product to fulfill its function. Capabilities include durability, reliability, resulting accuracy, ease of use, and other valuable repairs and features for all products. Product Quality is the ability of a product to provide performance results that match or even exceed the customer's great performance. (Kotler \& Keller, 2013). Product quality reflects the quality of all dimensions of a product offering that benefits the customer. The quality of products in the form of goods or services is determined according to dimensions (Tjiptono, 2017).

Brand awareness is the perceived value and trust of the product in the minds of consumers. This also affects risk assessment and consumer confidence in making purchase decisions according to the image of the product in mind (Siddiqui et al., 2016). Brand awareness can be defined as the ability of customers to differentiate and recognize brands in different contexts. Awareness can influence perceptions and attitudes. (Foroudi, 2019). Brand awareness is the main and most important limitation in any brand search and is the ability of consumers to recognize and remember brands in different situations. Brand awareness influences the consumer decision-making process about a product (Shahid et al., 2017). Brand Awareness is the ability of consumers to recognize the various features inherent in a product compared to other product brands. (Nasib \& Bashira, 2019).

Promotion is to notify, inform, present or disseminate a product to potential customers so that the prospective customer can finally make a purchase. (Prihastomo \& Usman, 2020). Promotion is an element in the company's marketing mix that is used to inform, persuade and remind the company's products. (Devy \& Anisa Br Sinulingga, 2018). This is to communicate information between sellers and potential buyers or others to influence promotions, attitudes and behavior. (Cannon, Joseph P., 2008). Promotion is all activities of producers to improve the quality of their products and persuade / persuade consumers to buy their products. (Gerung et al., 2017). The promotional mix includes advertising, personal selling, public relations and promotions, sales promotion and direct marketing. The promotion mix is part of the marketing incentive, a variable that can be controlled by the company. (Kotler \& Keller, 2013). 


\subsection{Research Framework}

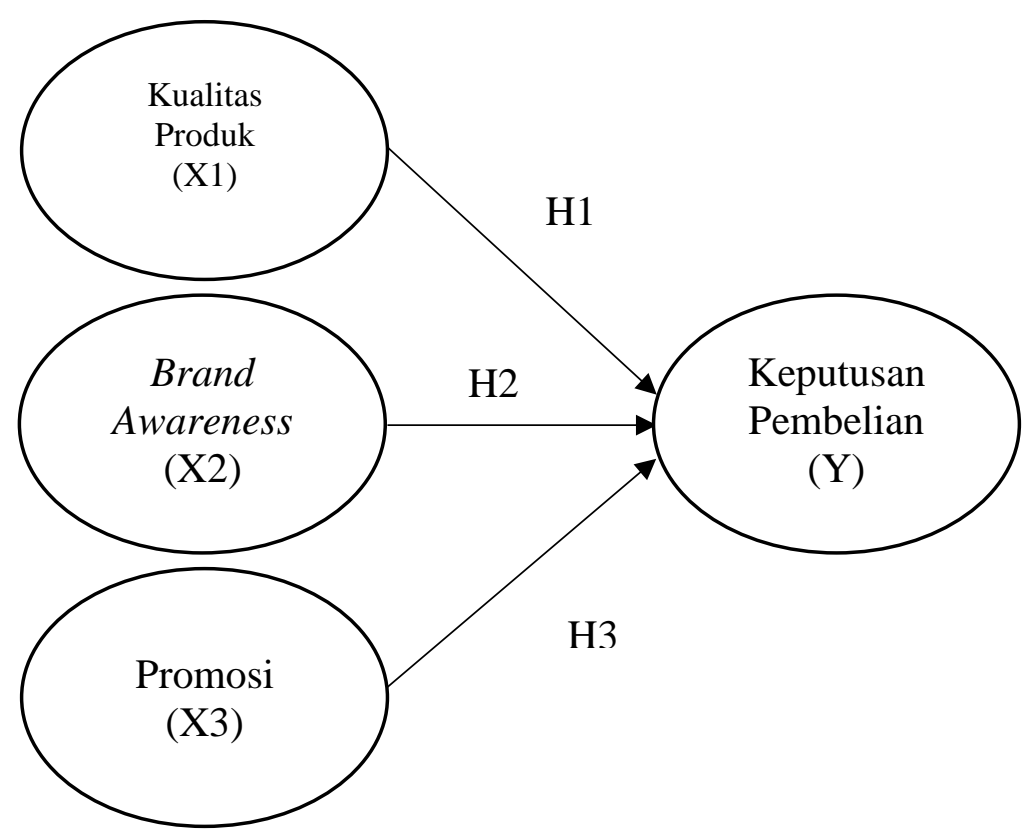

Figure 1: Conceptual Framework

The following hypothesis is proposed as a tentative answer based on the definition of the underlying problem and the formulation of the existing problem:

H1: Product quality has a positive and significant effect on the Suzuki Ertiga Purchase Decision in Cilegon, Banten

$\mathrm{H} 2$ : Brand Awareness has a positive and significant effect on the Suzuki Ertiga Purchase Decision in Cilegon, Banten

H3: Cilegon promotion has a positive and significant effect on the Suzuki Ertiga Purchase Decision in Banten

\section{RESEARCH METHODS}

\section{Population and Sample}

Population is an area of generalization consisting of objects or subjects with certain qualities and properties that are determined for the researcher to study and then draw conclusions. (Sugiyono, 2011). In this research, the population is customers who have purchased a Suzuki Ertiga car at least once in three years, from 2017 to 2019 at Suzuki Cilegon Dealer Restu Mahkota Karya.

according to (Hair Jr et al., 2016). Determining the minimum representative sample size depending on the number of indicators multiplied by five and ten. Referring to this, the number of 
samples in this study used 40 indicators multiplied by five - ten, so the researcher added the number of samples used in this study by five, so that the number of samples used in this study was at least 200 participants. The sampling technique in this study used purposive sampling method, namely the sampling method under certain conditions by determining certain sampling criteria.

\section{Method of collecting data}

Data collection techniques that are used in this study use library search and independent questionnaires. A literature search was carried out to obtain data on theories that support research. While the survey was carried out using data collection techniques, sending or sending a list of questions to be filled in by respondents themselves, using a survey given to customers who had purchased a Suzuki Ertiga at a Suzuki Cilegon Dealer Restu Mahkota from Google Form.

\section{FINDINGS AND DISCUSSION}

Thanks to the research, the data obtained from the research results are still in the form of raw data, the data must be processed and analyzed to determine and answer the research hypothesis. For this reason, the researcher tries to present a description of the data in this statement as follows:

Table 1: Demographic Characteristics of Respondents

\begin{tabular}{|c|c|c|c|}
\hline No & Descriptions & Frequency & Percentage $\%$ \\
\hline \multirow{3}{*}{1} & Gender & & \\
\hline & Man & 177 & 88,5 \\
\hline & Women & 23 & 11,5 \\
\hline \multirow{4}{*}{2} & Age & & \\
\hline & $23-28$ years & 17 & 8,5 \\
\hline & $29-34$ years & 73 & 36,5 \\
\hline & $>34$ years & 110 & 55 \\
\hline \multirow{5}{*}{3} & Profession & & \\
\hline & Employees & 131 & 65,5 \\
\hline & Entrepreneur & 32 & 16 \\
\hline & ASN & 31 & 15,5 \\
\hline & Housewife & 6 & 3 \\
\hline \multirow{4}{*}{4} & Education & & \\
\hline & Diploma & 30 & 15 \\
\hline & Undergraduate & 145 & 72,5 \\
\hline & Magister & 25 & 12,5 \\
\hline \multirow{3}{*}{5} & Income & & \\
\hline & Rp. 4.300 .000 - Rp. 5.000 .000 & 129 & 64,5 \\
\hline & Above IDR 5,000,000 & 71 & 35,5 \\
\hline
\end{tabular}

Source: Researcher Processed Data (2020)

\section{RESULT}

Component / Variance Based Structural Equation Modeling is an alternative to covariance based SEM, component-based SEM or variance, known as Partial Least Square (PLS). This method is 
designed for causal prediction analysis in situations with high complexity and low theory support"

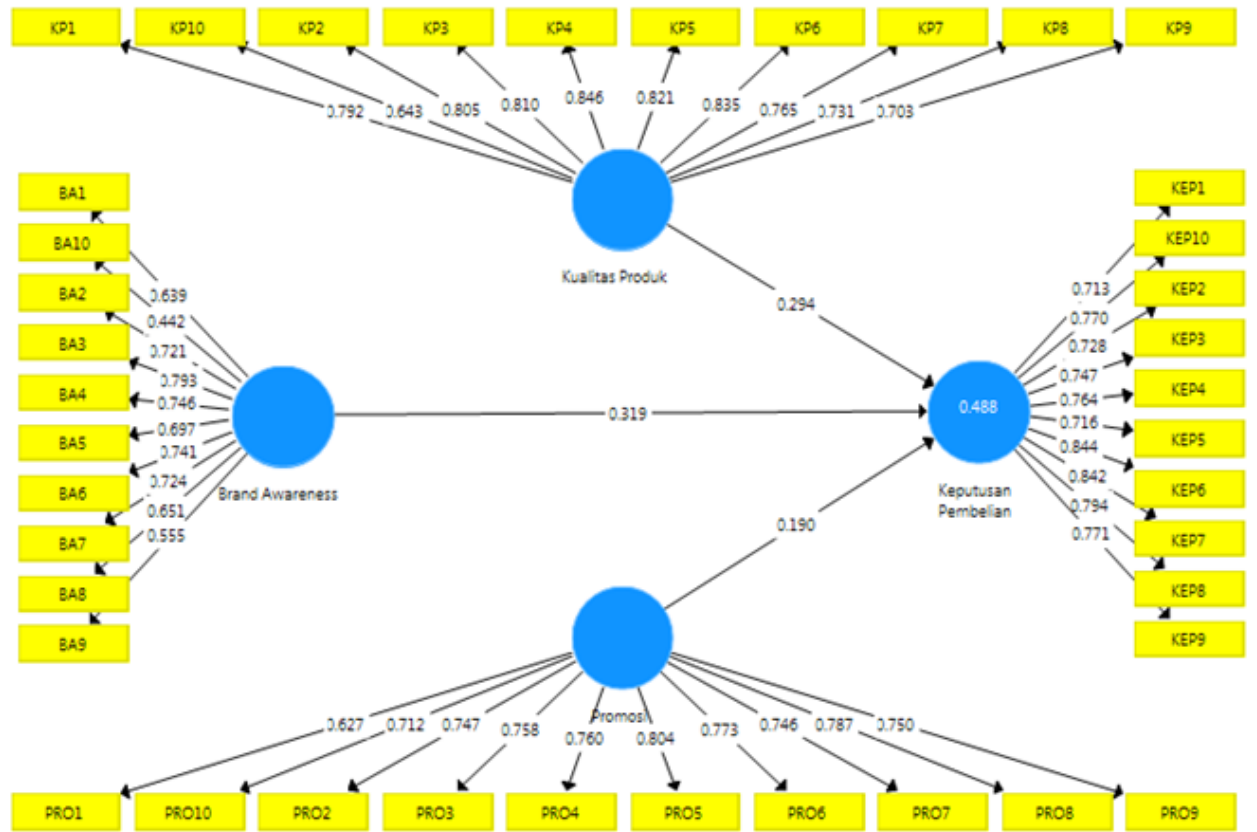

Figure 2 : Research Model

\section{Measurement Model}

\section{Convergent Validity}

The Convergent Validity Test of the measurement model with reflexive indicators was evaluated according to the correlation between the structure scores calculated by the PLS and the item / component scores. Individual indicators are considered valid if they have a correlation value above 0.70 . However, a loading factor scale of 0.50 to 0.60 is still acceptable during the research development stage.

Table 2: Loading Factor and reliability

\begin{tabular}{ccccc}
\hline Item & Loading & CR & AVE & Cronbach $\alpha$ \\
\hline BA1 & 0,676 & & & \\
BA2 & 0,747 & & & \\
BA3 & 0,819 & & & \\
BA4 & 0,769 & 0,897 & 0,523 & 0,869 \\
BA5 & 0,709 & & & \\
BA6 & 0,730 & & & \\
BA7 & 0,701 & & & \\
BA8 & 0,612 & & & \\
KEP1 & 0,714 & & &
\end{tabular}




\begin{tabular}{clll} 
KEP10 & 0,770 & & \\
KEP2 & 0,728 & & \\
KEP3 & 0,747 & 0,593 & 0,924 \\
KEP4 & 0,763 & & \\
KEP5 & 0,714 & & \\
KEP6 & 0,844 & & \\
KEP7 & 0,842 & & \\
KEP8 & 0,793 & & \\
KEP9 & 0,772 & & \\
KP1 & 0,802 & & \\
KP2 & 0,808 & & \\
KP3 & 0,820 & & \\
KP4 & 0,860 & & \\
KP5 & 0,836 & 0,931 & \\
KP6 & 0,840 & & \\
KP7 & 0,770 & & \\
KP8 & 0,727 & & \\
KP9 & 0,668 & \\
PRO10 & 0,715 & \\
PRO2 & 0,731 & & \\
PRO3 & 0,751 & & \\
PRO4 & 0,763 & & \\
PRO5 & 0,809 & \\
PRO6 & 0,782 & \\
PRO7 & 0,755 & & \\
PRO8 & 0,791 & \\
PRO9 & 0,758 & & \\
\hline & & & \\
\end{tabular}

Source: Results of data processing using SmartPLS 3.3.2, 2020

\section{Discriminant Validity}

You can also look at the differential validity test by looking at the Fornell Larcker Critical score for discriminatory validity. If the cross loading value of the indicator in a variable is the largest compared to other variables, it will be stated that the indicator meets the validity of the differentiator.

Table 3: Discriminant validity of construct Fornell-Larcker criterion.

\begin{tabular}{cccccc}
\hline No & & $\begin{array}{c}\text { Brand } \\
\text { Awareness }\end{array}$ & $\begin{array}{c}\text { Purchase } \\
\text { Decision }\end{array}$ & $\begin{array}{c}\text { Product } \\
\text { Quality }\end{array}$ & Promotion \\
\hline 1 & Brand Awareness & $\mathbf{0 , 7 2 3}$ & & & \\
2 & Purchase Decision & 0,607 & $\mathbf{0 , 7 7 0}$ & & \\
3 & Product Quality & 0,605 & 0,618 & $\mathbf{0 , 7 9 4}$ & \\
4 & Promotion & 0,568 & 0,579 & 0,667 & $\mathbf{0 , 7 6 2}$ \\
\hline
\end{tabular}

Source: Results of data processing using SmartPLS 3.3.2, 2020 


\section{Hyphothesis Testing}

The estimated values for the path relationships in the structural model must be significant. This significance value can be obtained by bootstrapping procedures. Seeing the significance of the hypothesis by looking at the parameter coefficient value and the T-statistical significance value on the bootstrapping report algorithm. To determine whether it is significant or not, it is seen from the T-table at alpha $0.05(5 \%)=1.96$. then, the T-table is compared by the T-count (T-statistic).

Based on the hypothesis testing in this study, the T-statistic value of Brand Awareness to Purchase Decisions is 5,108 and the $\mathrm{P}$ value is 0,000 . The T-statistic value is greater than the $\mathrm{T}$ table value of 1.96 and the $\mathrm{P}$ value shows a positive value, this result shows that Brand Awareness has a positive and significant effect on purchasing decisions. Based on hypothesis testing in this study, the T-statistic value of Product Quality on Purchasing Decisions is 2.956 and the $\mathrm{P}$ value is 0.003 . The T-statistic value is greater than the T-table value of 1.96 and the $\mathrm{P}$ value shows a positive value, this

Result shows that product quality has a positive and significant effect on purchasing decisions. Based on the hypothesis testing in this study, the T-statistic value of Promotion against Purchase Decisions is 2.396 and the $\mathrm{P}$ value is 0.017 . The T-statistic value is greater than the Ttable value of 1.96 and the $\mathrm{P}$ value shows a positive value, this result shows that promotion has a positive and significant effect on purchasing decisions.

Table 4: Hypothesis Testing Results

\begin{tabular}{ccccc}
\hline & Hipothesis & T Statistics & P Values & Information \\
\hline $\begin{array}{c}\text { Brand Awareness -> } \\
\text { Purchase Decision }\end{array}$ & H1 & 5,108 & 0,000 & $\begin{array}{c}\text { Positive - } \\
\text { Significant } \\
\text { Positive - } \\
\text { Product Quality -> Purchase }\end{array}$ \\
$\begin{array}{c}\text { Decision } \\
\begin{array}{c}\text { Promificant } \\
\text { Positive - } \\
\text { Significant }\end{array}\end{array}$ \\
\hline
\end{tabular}

Source: Results of data processing using SmartPLS 3.3.2, 2020

Figure 3: Model Structure 


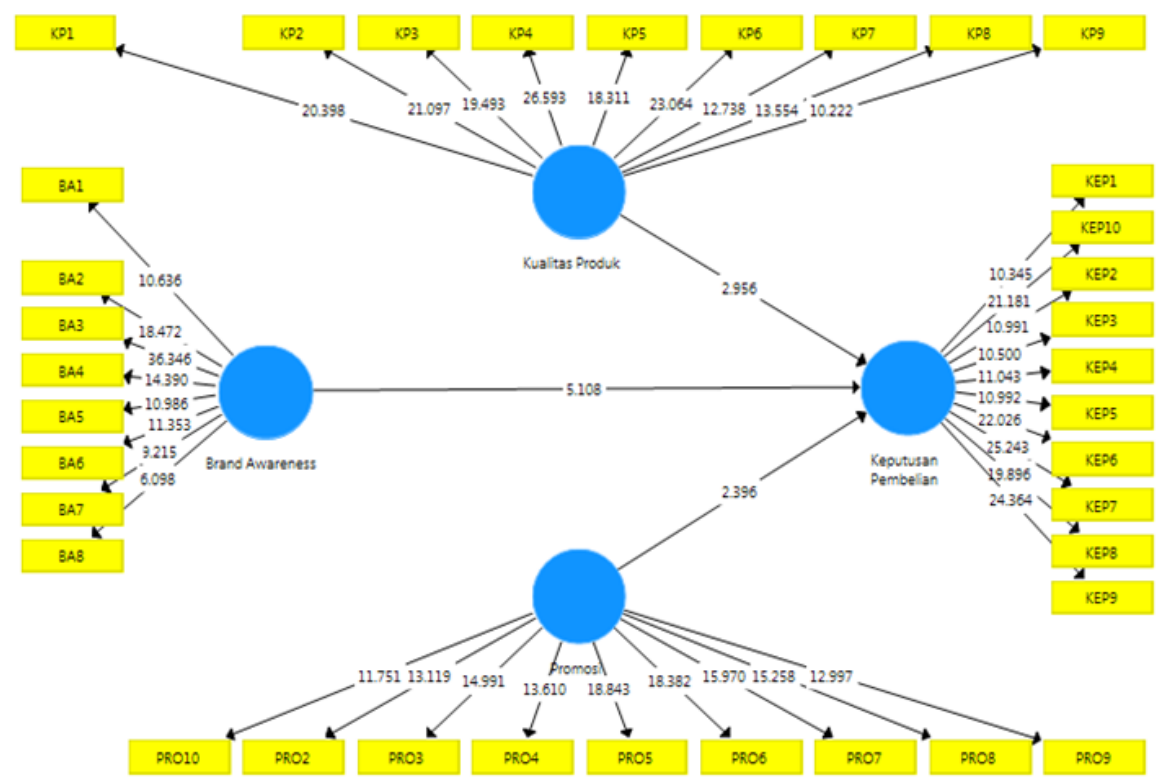

\section{Discussion \\ The Influence of Brand Awareness on Purchasing Decisions}

In testing the hypothesis where the Brand Awareness variable has a positive and significant influence on Purchasing Decisions. In line with research (Soomro \& Jawad, 2020) and (Subagja et al., 2019). it is evident that brand awareness has a significant effect on the purchasing decision-making process. That is, the better the Brand Awareness that is created, the higher the purchasing decision making process. The implication for the Suzuki Ertiga car in creating good Brand Awareness is that you have to pay attention to several things, especially on the dimensions with the strongest correlation being the Brand Recall dimension in the BA7 questionnaire, namely I often see the Suzuki Ertiga on the road / parking lot, this is proven when customers see the Suzuki Ertiga car in place. public or in a parking lot, the customer will know from every point of view on the car, but interestingly in the top of mind dimension with the BA9 questionnaire, the Suzuki Ertiga is the main alternative choice when I need a family vehicle, it turns out that consumers have not fully

provided the main alternative in looking for Low vehicle needs. MPV, so the company needs to carry out other strategies such as reintroducing the advantages of the Suzuki Ertiga so that consumers will be more aware of the Suzuki Ertiga car.

\section{The Influence of Product Quality on Purchasing Decisions}

Based on the hypothesis testing in this study, it shows that the product quality has a positive and significant effect on the decision to purchase a Suzuki Ertiga car at a Suzuki Cilegon Dealer Restu Mahkota Karya. This result is in line with the research conducted (Putro \& Nurmahdi, 2020), and (Amron, 2018). which states that Product Quality has a positive and significant effect on purchasing decisions, as evidenced in the KP1 questionnaire, namely Suzuki Ertiga has excellent engine performance obtaining a value The highest means that engine performance is prioritized by customers in choosing a car, of course what is done by Suzuki 
Ertiga by providing excellent engine quality where having a reliable engine certainly makes the Suzuki Ertiga car the choice of customers in buying the car, but vice versa. The weakest correlation in the KP9 questionnaire is that the overall design of the Suzuki Ertiga is more stylish and modern, which means that what is provided by the Suzuki Ertiga has not provided what customers expect, so the Suzuki Ertiga car manufacturer needs to innovate again in accordance with the growing trend.

\section{Effect of Promotion on Purchasing Decisions}

Based on the hypothesis test in this study, the results show that promotion has a positive and significant effect on the decision to purchase a Suzuki Ertiga car at a Suzuki Cilegon Dealer Restu Mahkota Karya. This result is reinforced by research (Rahman \& Sitio, 2020) and (Prihastomo \& Usman, 2020). which state that in a promotion there is a marketing communication process formed through information so that it will affect consumer behavior in buying a Suzuki Ertiga car, proven to be the highest index in Promotion at questionnaire PRO5 I saw Suzuki Ertiga ads through social networks, such as Instagram, YouTube, etc. which means that advertising through social networks has a very strong effect on sales, it is proven that the highest index in customer promotion in finding references is done by viewing ads on social networks because they are easy to reach and right on target. While the weak correlation is in the Product Recommendation by Email indicator with the PRO9 questionnaire, namely I get a Suzuki Ertiga discount through social networks, email, etc. which means that customers do not necessarily get a discount through social networks, where the sales department at the Suzuki dealer is the one who most played a major role in informing the discount.

\section{CONCLUSION AND RECOMMENDATION}

From the results of the research and discussion obtained, it can be concluded as follows:

1. Product quality has a positive and significant effect on the purchase decision of a Suzuki Ertiga car in Cilegon City.

2. Brand Awareness has a positive and significant effect on the purchase decision of a Suzuki Ertiga in Cilegon City.

3. Promotion has a positive and significant effect on the decision to buy a Suzuki Ertiga in Cilegon City

Based on the above conclusions, several suggestions can be put into consideration for Suzuki Cilegon Dealer Restu Mahkota Karya and further research, namely as follows:

1. Advice for Suzuki Cilegon Dealer Restu Mahkota Karya

a. In the lowest index product quality variable in statement ten with the KP9 questionnaire, namely the overall design of the Suzuki Ertiga is more stylish and modern, which means that customers think that the design owned by the Suzuki Ertiga car still does not provide the best for customers, of course suggestions from researchers are necessary. reinnovating in terms of interior and exterior design so that they can compete with competitors who first innovated from these things, for example from exterior design such as paint colors that are different from competitors and can be seen from a unique side of course it will add sales value to Suzuki Ertiga car. 
b. The lowest Brand Awareness Index variable is in the Nine statement with the BA9 questionnaire, namely Suzuki Ertiga is the main alternative choice when I need a family vehicle, which means that the customer has not fully provided alternative choices for the Suzuki Ertiga car, so the suggestions that need to be done by The dealer, namely the need to introduce the Suzuki Ertiga again with various things such as advertising the car so that the Suzuki Ertiga car will be the main alternative choice in finding a vehicle, then the most important thing is to expand the sales network such as opening new dealer branches in areas that are not yet looking for a family vehicle, immediately remember the Suzuki Ertiga.

c. In the lowest Promotion Index variable in statement nine with the PRO9 questionnaire, namely I get a Suzuki Ertiga discount through social networks, email, etc., which means that customers still think that consumers still have not fully gotten a discount through these social networks, therefore suggestions which can be used as a consideration for Suzuki Cilegon Dealer Restu Mahkota Karya, namely being able to increase marketing by providing more vigorous price discounts through social networks so that it will certainly attract more consumers to buy Suzuki Ertiga cars.

2. For further researchers

a. This study focuses on 4 variable studies, namely, product quality, brand awareness, promotion and purchase decisions so that the use of other variables such as brand image, price, service quality, location and other variables need to be carried out in future research in order to produce a more detailed picture. broad about the research problem that is being researched, then further research is expected to be able to carry out both studies, namely qualitative and quantitative to provide more in-depth and informative research results that can provide suggestions or other ideas

In addition to the alternatives above, further research should use a different object, so that it is expected to produce a clearer picture of purchasing decisions

\section{REFFERENCES}

Amron, A. (2018). Effects of Product Quality, Price, and Brand Image on the Buying Decision of City Car Product. Archives of Business Research, 6(4), 1-8. https://doi.org/10.14738/abr.64.4374

Broto, V., \& Wenas, R. S. (2016). Analisis Citra Merek, Kualitas Produk, Dan Fasilitas Terhadap Keputusan Pembelian Konsumen Mobil Toyota Agya Pada Pt.Hasjrat Abadi Cabang Bitung. Jurnal Riset Ekonomi, Manajemen, Bisnis Dan Akuntansi, 4(2), 154-163.

Cannon, Joseph P., W. D. P. J. dan J. M. (2008). Dasar-Dasar Pemasaran: Pendekatan Manajerial Global. (Salemba Empati (ed.); Edisi 16).

Carmudi. (2020). Daftar Harga Mobil Low MPV Terbaru, Paling Murah Rp150 Jutaan. https://www.carmudi.co.id/journal/daftar-harga-mobil-low-mpv-terbaru-paling-murahrp150-jutaan/

Devy, S., \& Anisa Br Sinulingga, N. (2018). Pengaruh Harga dan Promosi terhadap Keputusan 
Pembelian Sepeda Motor pada PT. Rotella Persada Mandiri. Journal of Management Science (JMAS), 1(1), 2684-9747. http://exsys.iocspublisher.org/index.php/JMAS

Fong, S. W. L., Kian, T. P., Fern, Y. S., \& Vincent, W. (2015). Monetary and Image Influences on the Purchase Decision of Private Label Products in Malaysia. Journal of Advanced Management Science, 3(4), 312-318. https://doi.org/10.12720/joams.3.4.312-318

Foroudi, P. (2019). Influence of brand signature, brand awareness, brand attitude, brand reputation on hotel industry's brand performance. International Journal of Hospitality Management, 76(May), 271-285. https://doi.org/10.1016/j.ijhm.2018.05.016

Gerung, C. J., Sepang, J., \& Loindong, S. (2017). Pengaruh Kualitas Produk, Harga Dan Promosi Terhadap Keputusan Pembelian Mobil Nissan X-Trail Pada Pt. Wahana Wirawan Manado. Jurnal EMBA: Jurnal Riset Ekonomi, Manajemen, Bisnis Dan Akuntansi, 5(2), 2221-2229. https://doi.org/10.35794/emba.v5i2.16521

Hair Jr, J. F., Hult, G. T. M., Ringle, C., \& Sarstedt, M. (2016). A primer on partial least squares structural equation modeling (PLS-SEM). Sage publications.

Jayaraj, A. M. (2017). a Study on Consumer Behaviour Towards Two Wheeler Dealers. 7(4), 418-424.

Khuong, M. N., \& Duyen, H. T. M. (2016). Personal Factors Affecting Consumer Purchase Decision towards Men Skin Care Products - A Study in Ho Chi Minh City, Vietnam. International Journal of Trade, Economics and Finance, 7(2), 44-50. https://doi.org/10.18178/ijtef.2016.7.2.497

Kotler, P., \& Keller, K. L. (2013). Manajemen Pemasaran, Jilid Kedua. Jakarta: Erlangga.

Mayil, M. V., Anusuya, C., \& Pandian, H. S. V. (2016). a Study on Consumer Behavior Towards Cell Phone With. 6(5), 667-676.

Mustari, R. K. A., Asdar, M., \& Sudirman, I. (2016). Effect of marketing communications, brand equity, brand awareness attitudes, and decision of customers PT. Mortgage in South Sulawesi. International Journal of Scientific and Research Publications, 6(8), 574-581.

Nasib, N., \& Bashira, B. (2019). Pengaruh Brand Awareness Dan Loyalitas Merek Terhadap Keputusan Pembelian Sepeda Motor Yamaha Matic. Jurnal Manajemen Dan Keuangan, 8(1), 34-42. https://doi.org/10.33059/jmk.v8i1.1137

Otoflik. (2020). 35 Merek Mobil Beserta Asal Negara Terbaik Indonesia \& Dunia 2021. https://www.otoflik.com/merek-mobil/

Peter, J. P., \& Olson, J. C. (1987). Consumer behavior: Marketing strategy perspectives. Irwin.

Prihastomo, G., \& Usman, O. (2020). The Effect of Product Quality, Price, Promotion, and Lifestyle on Purchase Decisions to Drink the Coffee. SSRN Electronic Journal. https://doi.org/10.2139/ssrn.3510779

Putro, C. H., \& Nurmahdi, A. (2020). Analysis of Purchase Decision and its Impacts towards 
Honda Beat Motorcycle's Customer Satisfaction Viewed through Product Quality and Price Perception Variables at Tangerang City Area. 5(6), 1222-1229.

Rahman, H. A., \& Sitio, A. (2020). the Effect of Promotion and Product Quality Through Purchase Decision on the Customer Satisfaction of Bohemian Project.Id Products. International Journal of Engineering Technologies and Management Research, 6(1), 5572. https://doi.org/10.29121/ijetmr.v6.i1.2019.346

Salem, M. Z. (2018). Effects of perfume packaging on Basque female consumers purchase decision in Spain. Management Decision, 56(8), 1748-1768. https://doi.org/10.1108/MD04-2017-0363

Schiffman, L., \& Kanuk, L. L. (2008). Perilaku konsumen. Jakarta: Indeks.

Shahid, Z., Hussain, T., \& Zafar, F. (2017). The Impact of Brand Awareness on the Consumers' Purchase Intention. Journal of Accounting \& Marketing, 06(01), 1-4. https://doi.org/10.4172/2168-9601.1000223

Sheroog Alhedhaif, Lele, U., \& Kaifi, B. A. (2016). Brand Loyalty and Factors Affecting Cosmetics Buying Behavior of Saudi Female Consumers. Journal of Business Studies Quarterly, 7(3), 24-38.

Siddiqui, K. A., Tarani, S. S. A., Fatani, S. A., Raza, A., Butt, R. M. B., \& Azeema, N. (2016). Effect of Size, Location and Content of Billboards on Brand Awareness. Journal of Business Studies Quarterly, 8(2).

Soomro, \& Jawad, H. (2020). Intervening analysis of internet marketing between the relationship of brand awareness and online purchase decision of mobile products among the students of Heis in Pakistan. Indian Journal of Science and Technology, 13(15), 1535-1545. https://doi.org/10.17485/ijst/v13i15.39

Subagja, I. K., Alamsyah, N., Silitonga, E. S., \& Indratjahyo, H. (2019). Brand Awareness and

Quality Product on Purchase Decision Mediating Consumer Perception: Case Study in PT. Tugu Pratama Indonesia. South Asian Research Journal of Business and Management, 01(03), 85-90. https://doi.org/10.36346/sarjbm.2019.v01i03.001

Sugiyono, P. (2011). Metodologi penelitian kuantitatif kualitatif dan R\&D. Alpabeta, Bandung.

Suzuki.co.id. (2019). All New Ertiga Raih Car of the Year di Otomotif Award. Www.Suzuki.Co.Id. https://www.suzuki.co.id/news/all-new-ertiga-raih-car-of-the-year-diotomotif-award

Tawas, H., \& Pandensolang, J. (2015). Pengaruh Diferensiasi, Kualitas Produk Dan Ekuitas Merek Terhadap Keputusan Pembelian Coca-Cola Pada Pt. Bangun Wenang Beverges Company Di Manado. Jurnal Riset Ekonomi, Manajemen, Bisnis Dan Akuntansi, 3(3), 1113-1124.

Tjiptono, F. (2017). Strategi pemasaran (Edisi Ke E). Andi. 
Wangean, R. H., \& Mandey, S. L. (2014). Analisis Citra Merek, Kualitas Produk Dan Harga Pengaruhnya Terhadap Keputusan Pembelian Konsumen Pada Mobil All New Kia Rio Di Kota Manado. Jurnal Riset Ekonomi, Manajemen, Bisnis Dan Akuntansi, 2(3), 1715-1725.

Wibisono, K. (2017). Cerita di balik larisnya mobil MPV di Indonesia. Www.Otomotif.Antaranews.Com. https://otomotif.antaranews.com/berita/619919/cerita-dibalik-larisnya-mobil-mpv-di-indonesia

Xu, L., Blankson, C., \& Prybutok, V. (2017). Relative contributions of product quality and service quality in the automobile industry. Quality Management Journal, 24(1), 21-36. https://doi.org/10.1080/10686967.2017.11918498 